ISSN : 2354-5852

e-ISSN : 2579-5783

\title{
Korelasi Teknik Pelaksanaan Inisiasi Menyusu Dini (IMD) dengan Kejadian Perdarahan Post Partum
}

\author{
Suprapti ${ }^{1}$ \\ Akademi Kebidanan Delima Persada Gresik, Indonesia ${ }^{1}$ \\ e-mail: supraptiprobo@gmail.com
}

\begin{abstract}
Early breastfeeding is an initial activity in providing breast milk to babies which have the advantage on the health of your baby's growth and development and fostering ties of affection between mother and baby. Early breastfeeding is also an effort to increase the contractions of the uterus that can reduce the occurrence of bleeding. The purpose of this study is to determine the relationship between technical implementation of IMD with the incidence of postpartum haemorrhage.This research uses analytic observational design by the cross sectional approach. Independent variable is the technical implementation of the IMD and the dependent variable was the incidence of postpartum haemorrhage. The subject of this study was 30. Data was collecting by a checklist and be analyzed using the Fisher Exact Test. The results show that mothers who carry out technical implementation of the corresponding IMD were 21 people (70\%) and who carry out technical implementation of the IMD that does not fit as many as 9 people (30\%). While mothers who experience postpartum haemorrhage are 3 people (10\%) and did not experience postpartum haemorrhage are 27 people (90\%). The fisher exact test show score of $\rho$ value was 0.207 . So there is no relationship between the technical implementation of the IMD with the incidence of postpartum haemorrhage. So this result can be used as the basis to give the information for the health workers (midwives) about the importance of prevention of postpartum haemorrhage by remaining obediently carry out the standard APN by IMD and by improving human resources through sustainable education, and joining the training for the health care.
\end{abstract}

Keywords : haemoraghic, IMD, post partum

\section{Pendahuluan}

Kehamilan dan melahirkan menimbulkan resiko kesehatan yang besar, termasuk bagi perempuan yang tidak mempunyai masalah kesehatan sebelumnya. Sebagian besar kematian tersebut terjadi karena perempuan sering kurang mendapat akses terhadap perawatan penyelamatan hidup. Perempuan lebih cenderung mendapat perawatan antenatal atau perawatan sebelum melahirkan dibandingkan mendapat perawatan kebidanan yang seharusnya diterima selama persalinan atau pasca persalinan. Kenyataanya lebih dari separuh jumlah seluruh kematian ibu terjadi dalam 24 jam setelah melahirkan, sebagian besar karena terlalu banyak mengeluarkan darah. Perdarahan hebat adalah penyebab yang paling utama dari kematian ibu di persalinan (Syaifuddin, 2002)

Angka Kematian Ibu (AKI) di Indonesia mengalami penurunan yang cukup signifikan dari tahun 2004 sampai tahun 2007. Pada tahun 2004, angka kematian ibu berkisar antara 270 per 100.000 kelahiran hidup. Pada tahun 2005 yang diperoleh dari Badan Penelitian Statistik (BPS), diketahui bahwa angka kematian ibu berkisar antara 262 per 100.000 kelahiran hidup dan pada tahun 2006 angka kematian ibu berkisar antara 252 per 100.000 kelahiran hidup. Sedangkan di tahun 2007 angka kematian ibu berkisar antara 248 per 100.000 kelahiran. Dan pada tahun 2008 angka kematian ibu mencapai 101 dari 22.818 kelahiran hidup. Hal ini masih jauh dari target yang dinginkan pemerintah yaitu 226 per 100.000 kelahiran hidup pada tahun 2009.

Penyebab kematian utama ibu di Indonesia adalah perdarahan. Penyebab kedua adalah eklampsia dan infeksi (Palupi, D. D., \& Indawati, R., 2014). Perdarahan dapat disebabkan karena beberapa hal diantaranya atonia uteri (50-60\%), sisa plasenta (23-24\%), retentio plasenta (16-17\%), laserasi jalan lahir $(4-5 \%)$, dan kelainan darah $(0,5-0,8 \%)$ (Doengoes, 2001). Perdarahan postpartum akibat atonia uteri merupakan penyebab terbanyak (Moedjiarto, S, 2011). Salah satu cara pemerintah untuk mengurangi kejadian perdarahan adalah dengan memberikan ASI sedini mungkin, dikenal dengan istilah Inisiasi Menyusui Dini (IMD) yaitu bayi disusui segera setelah lahir dengan cara meletakkan diatas 
dada ibu (Roesli, H.U, 2008). Harapan pemerintah terhadap dilakukannya program IMD harus mencapai $100 \%$. Hal ini sangat mudah dilaksanakan, hanya saja ada beberapa faktor yang mendukung keberhasilannya yaitu tergantung kesiapan fisik dan psikologi yang sudah harus dipersiapkan dari awal kehamilannya. Konseling dalam pemberian informasi mengenai inisiasi menyusui dini bisa diberikan selama kehamilan (Awang, M. N, 2014).

Saat melakukan IMD, sentuhan, hisapan dan jilatan bayi pada puting ibu akan merangsang keluarnya hormon oksitosin yang penting untuk beberapa hal, antara lain merangsang kontraksi uterus untuk membantu pengeluaran plasenta dan mengurangi perdarahan ibu. Selain oksitosin, IMD juga merangsang keluarnya prolaktin yang dapat meningkatkan aliran ASI untuk proses menyusui. Gerakan bayi yang merangkak dan menginjak perut ibu diatas rahim, dapat membantu uterus berkontraksi dan menghentikan perdarahan (Roesli, H.U, 2008).

Menurut data dari Dinas Kesehatan Gresik, Puskesmas Bungah merupakan Puskesmas dengan kejadian resiko tinggi tertinggi yang kedua yaitu sebesar 148 kasus. Data studi pendahuluan di wilayah kerja Puskesmas Bungah Gresik diketahui bahwa pada bulan Januari - Juni tahun 2016 jumlah persalinan mencapai 44 ibu dan pada bulan Juli - Desember tahun 2016 jumlah persalinan mencapai 37 ibu dan semuanya sudah melakukan IMD. Akan tetapi dari 44 ibu melahirkan pada bulan Januari - Juni terdapat 2 ibu $(4,5 \%)$ melahirkan yang mengalami perdarahan dan pada bulan Juli - Desember dari $37 \mathrm{ibu}$ melahirkan terdapat $4 \mathrm{ibu}(10,8 \%)$ melahirkan yang mengalami perdarahan. Hal ini menunjukkan adanya peningkatan kejadian perdarahan postpartum sebesar $100 \%$ di wilayah kerja Puskesmas Bungah.

Dampak yang dapat ditimbulkan apabila kejadian perdarahan postpartum terus meningkat adalah terjadi resiko peningkatan Angka Kematian Ibu (AKI). Namun pada kenyataannya, meskipun IMD sudah dilakukan secara $100 \%$ akan tetapi kejadian tetap terjadi bahkan pada akhir tahun 2016 tepatnya 6 bulan terakhir bulan Juli - Desember 2016 terdapat 4 kejadian perdarahan dari 37 persalinan. Hal ini dipengaruhi oleh ibu anemia, retensio plasenta, atonia uteri, dan salah satunya yaitu teknik pelaksanaan IMD oleh petugas kesehatan khususnya penolong persalinan yang kurang tepat.

Berbagai upaya telah dilakukan oleh pemerintah melalui peningkatan mutu pelayanan, penyuluhan kesehatan, pelatihan pelatihan kepada petugas kesehatan khususnya bidan yang dimana seluruh kegiatan tersebut bertujuan untuk menekan terjadinya perdarahan postpartum sehingga Angka Kematian Ibu (AKI) bisa ditekan. Adapun solusi lain yang dapat dilakukan oleh tenaga kesehatan, khususnya bidan yang dalam hal ini sebagai ujung tombak pelayanan kesehatan kepada masyarakat harus senantiasa meningkatkan Sumber Daya Manusia (SDM) melalui pendidikan berkelanjutan, mengikuti pelatihan - pelatihan yang berhubungan dengan pelayanan kesehatan, dan lain sebagainya. Hal ini sangat perlu dilakukan agar dalam memberikan pelayanan kesehatan klien bisa merasa puas terhadap pelayanan yang diberikan oleh bidan.

Berdasarkan uraian diatas, maka peneliti terdorong untuk melakukan penelitian tentang Korelasi Teknik Pelaksanaan IMD dengan Kejadian Perdarahan Postpartum di Wilayah Kerja Puskesmas Bungah Gresik tahun 2016, sebagai upaya untuk menurunkan Angka Kematian Ibu (AKI) dengan cara mencegah perdarahan postpartum sesuai dengan Asuhan Persalinan Normal (APN) dengan menerapkan Inisiasi Menyusui Dini (IMD).

\section{Metode}

Penelitian ini menggunakan rancangan penelitian observasional dengan pendekatan cross sectional yang merupakan rancangan penelitian dengan melakukan pengukuran atau pengamatan pada saat bersamaan (sekali waktu) antara faktor resiko / paparan dengan penyakit.

\subsection{Metode Pengumpulan Data}

Variabel dalam penelitian ini adalah teknik pelaksanaan IMD variabel independen dan kejadian perdarahan persalinan sebagai variabel dependen.

Populasi pada penelitian ini adalah seluruh Ibu bersalin selama 2 jam PP di wilayah kerja Puskesmas Bungah Gresik tahun 2016.

Jurnal Kesehatan Vol. 6. No. 1. April 2018 |7 
Subyek penelitian adalah 36 ibu postpartum yang diambil secara random ditemukan 30 responden. Instrumen pengumpulan pada penelitian ini menggunakan ceklist dengan cara melakukan observasi langsung pada responden dan mencatat hasil pengamatan ke dalam ceklist yang sudah disediakan.

\subsection{Metode Analisis Data}

Analisis data dalam penelitian ini terdiri dari analisis univariat berupa table distribusi frekuensi dan analisis bivariat dengan menggunakan Fisher Exact Test. Penarikan kesimpulan dilakukan dengan membandingkan $\mathrm{p}$ value dengan $\alpha=0,05$. Jika $\mathrm{p}$ value $<\alpha=0,05$ maka Ho ditolak, Ha diterima artinya ada hubungan teknik pelaksanaan IMD dengan kejadian perdarahan postpartum.

\section{Hasil dan pembahasan}

Data umum meliputi distribusi responden berdasarkan usia, pendidikan, pekerjaan, dan kehamilan. Karakteristik responden berdasarkan umur dapat dilihat pada tabel 1.

Tabel 1. Distribusi frekuensi berdasarkan umur ibu bersalin di Wilayah Kerja Puskesmas Bungah Gresik

\begin{tabular}{ccc}
\hline Umur & Frekuensi (f) & $\begin{array}{c}\text { Presentase } \\
(\mathbf{\%})\end{array}$ \\
\hline$<20$ tahun & 1 & 3,3 \\
$20-35$ tahun & 27 & 90 \\
$>35$ tahun & 2 & 6,7 \\
Jumlah & 30 & 100 \\
\hline
\end{tabular}

Berdasarkan tabel 1 diketahui bahwa dari 30 responden sebagian besar berumur 20 35 tahun yaitu sebanyak 27 responden $(90 \%)$. Dan sebagian kecil berumur $<20$ tahun yaitu sebanyak 1 responden $(3,3 \%)$.

Karakteristik responden berdasarkan paritas disajikan dalam tabel 2.

Tabel 2. Distribusi frekuensi berdasarkan paritas ibu bersalin di Wilayah Kerja Puskesmas Bungah Gresik

\begin{tabular}{ccc}
\hline Paritas & Frekuensi (f) & $\begin{array}{c}\text { Presentase } \\
(\%)\end{array}$ \\
\hline Primipara & 15 & 50 \\
Multipara & 15 & 50 \\
Grandemulti & 0 & 0
\end{tabular}

Jumlah 30 30

Berdasarkan tabel 2 diketahui bahwa dari 30 responden jumlah primipara dan multipara sama besar yaitu 15 responden $(50 \%)$. Dan tidak ada responden yang grandemulti.

Gambaran teknik Penatalaksanaan IMD ibu bersalin di wilayah kerja Puskesmas Bungah Gresik dapat dilihat pada tabel 3.

Tabel 3. Distribusi frekuensi berdasarkan teknik pelaksanaan IMD pada ibu bersalin di Wilayah Kerja Puskesmas Bungah Gresik

\begin{tabular}{ccc}
\hline $\begin{array}{c}\text { Teknik } \\
\text { Pelaksanaan } \\
\text { IMD }\end{array}$ & $\begin{array}{c}\text { Frekuensi } \\
\text { (f) }\end{array}$ & $\begin{array}{c}\text { Presentase } \\
\text { (\%) }\end{array}$ \\
\hline Sesuai & 21 & 70 \\
Tidak Sesuai & 9 & 30 \\
Jumlah & 30 & 100 \\
\hline
\end{tabular}

Berdasarkan tabel 3 diketahui bahwa dari 30 responden sebagian besar yang melakukan teknik pelaksanaan IMD yang sesuai yaitu sebanyak 21 responden $(70 \%)$. Dan yang melakukan teknik pelaksanaan IMD yang tidak sesuai yaitu sebanyak 9 responden $(30 \%)$.

Analisis bivariat deskriptif teknik Pelaksanaan IMD dengan Umur disajikan dalam tabel 4.

Tabel 4. Distribusi frekuensi antara umur dan teknik pelaksanaan IMD pada ibu bersalin di Wilayah Kerja Puskesmas Bungah Gresik

\begin{tabular}{ccccc}
\hline $\begin{array}{c}\text { Teknik } \\
\text { Pelaksanaan IMD }\end{array}$ & $\mathbf{2 0}$ & $\mathbf{2 0 - 3 5}$ & $>\mathbf{3 5}$ & Jumlah \\
\hline Sesuai & 1 & 20 & 0 & 21 \\
Tidak Sesuai & 0 & 7 & 2 & 9 \\
Jumlah & 1 & 27 & 2 & 30 \\
\hline
\end{tabular}

Berdasarkan tabel 4 diketahui bahwa dari 30 responden sebagian besar yang melakukan teknik pelaksanaan IMD yang sesuai adalah responden dengan usia 20-35 tahun yaitu sebanyak 20 responden $(66,7 \%)$. Dan terdapat 1 responden (3,3\%) yang berumur $<20$ tahun yang melakukan teknik pelaksanaan IMD yang sesuai.

8 | Jurnal Kesehatan Vol. 6. No. 1. April 2018 
Analisis bivariat deskriptif paritas dengan teknik pelaksanaan IMD dapat dilihat pada tabel 5 .

Tabel 5. Distribusi frekuensi antara paritas dan teknik pelaksanaan IMD pada ibu bersalin di Wilayah Kerja Puskesmas Bungah Gresik

\begin{tabular}{ccccc}
\hline $\begin{array}{c}\text { Teknik } \\
\text { Pelaksanaan } \\
\text { IMD }\end{array}$ & $\begin{array}{c}\text { Primi } \\
\text { para }\end{array}$ & $\begin{array}{c}\text { Multi } \\
\text { para }\end{array}$ & $\begin{array}{c}\text { Grand } \\
\text { emulti }\end{array}$ & Jml \\
\hline Sesuai & 12 & 9 & 0 & 21 \\
Tidak Sesuai & 3 & 6 & 0 & 9 \\
Jumlah & 15 & 15 & 0 & 30 \\
\hline
\end{tabular}

Berdasarkan tabel 5 diketahui bahwa dari 30 responden yang melakukan teknik pelaksanaan IMD yang tidak sesuai adalah pada primipara sebanyak 3 responden $(10 \%)$. Dan pada multipara yang tidak melakukan teknik pelaksanaan IMD yang tidak sesuai sebanyak 6 responden $(20 \%)$.

Gambaran kejadian perdarahan postpartum disajikan dalam tabel 6 .

Tabel 6. Distribusi frekuensi berdasarkan kejadian perdarahan postpartum pada ibu bersalin di Wilayah Kerja Puskesmas Bungah Gresik

\begin{tabular}{ccc}
\hline $\begin{array}{c}\text { Perdarahan } \\
\text { Postpartum }\end{array}$ & Frekuensi (f) & $\begin{array}{c}\text { Presentase } \\
(\%)\end{array}$ \\
\hline Ya & 3 & 10 \\
Tidak & 27 & 90 \\
Jumlah & 30 & 100 \\
\hline
\end{tabular}

Berdasarkan tabel 6 diketahui bahwa dari 30 responden terdapat 3 responden (10\%) yang mengalami perdarahan pospartum dan terdapat 27 responden (90\%) yang tidak mengalami perdarahan postpartum.

Analisis bivariat deskriptif umur dengan perdarahan postpartum disajikan dalam tabel 7 .

Tabel 7. Distribusi frekuensi antara umur dan kejadian perdarahan postpartum pada ibu bersalin di Wilayah Kerja Puskesmas Bungah Gresik

\begin{tabular}{ccccc}
\hline $\begin{array}{c}\text { Perdarahan } \\
\text { Postpartum }\end{array}$ & \multicolumn{5}{c}{ Umur } & $\mathbf{2 0 - 3 5}$ & $>\mathbf{3 5}$ & Jml \\
\hline Ya & 1 & 0 & 2 & 3 \\
\hline
\end{tabular}

\begin{tabular}{rrrrr}
\hline Tidak & 0 & 27 & 0 & 27 \\
Jumlah & 1 & 27 & 2 & 30 \\
\hline
\end{tabular}

Berdasarkan tabel 7 diketahui bahwa dari 30 responden yang mengalami perdarahan terjadi pada umur $<20$ tahun sebanyak 1 responden $(3,3 \%)$ dan pada umur $>35$ tahun sebanyak 2 responden $(6,7 \%)$. Dan yang berumur 20-35 tahun tidak ada yang mengalami perdarahan postpartum sebanyak 27 responden (90\%).

Analisis bivariat deskriptif paritas dengan perdarahan postpartum dapat dilihat pada tabel 8 .

Tabel 8. Distribusi frekuensi antara paritas dan kejadian perdarahan postpartum pada ibu bersalin di Wilayah Kerja Puskesmas Bungah

\begin{tabular}{ccccc}
\hline & \multicolumn{5}{c}{$\begin{array}{l}\text { Paritas } \\
\text { Prim } \\
\text { Mult } \\
\text { ipar } \\
\text { Postparah }\end{array}$} & $\begin{array}{c}\text { Grand } \\
\text { ipan }\end{array}$ & $\begin{array}{c}\text { a } \\
\text { a }\end{array}$ & $\begin{array}{c}\text { Jmlti } \\
\text { Ya }\end{array}$ & 1 & 2 & 0 & 3 \\
Tidak & 14 & 13 & 0 & 27 \\
Jumlah & 15 & 15 & 0 & 30 \\
\hline
\end{tabular}

Berdasarkan tabel 5.8 diketahui bahwa terdapat 1 primipara $(3,3 \%)$ dan 2 multipara $(6,7 \%)$ yang mengalami perdarahan potpartum.

Hubungan teknik penatalaksanaan IMD dengan kejadian perdarahan postpartum disajikan dalam tabel 9.

Tabel 9. Tabulasi silang antara teknik pelaksanaan IMD dengan kejadian perdarahan postpartum pada ibu bersalin di Wilayah Kerja Puskesmas Bungah

\begin{tabular}{ccccccc}
\hline \multirow{2}{*}{$\begin{array}{c}\text { Teknik } \\
\text { Pelaksanaan } \\
\text { IMD }\end{array}$} & \multicolumn{3}{c}{$\begin{array}{c}\text { Kejadian } \\
\text { Perdarahan }\end{array}$} & & Postpartum \\
& Terjadi & \multicolumn{2}{c}{ Tidak } & & Jumlah \\
\cline { 2 - 7 } Sesuai & 1 & 3,3 & 20 & 66,7 & 21 & 70 \\
Tidak sesuai & 2 & 6,7 & 7 & 23,3 & 9 & 30 \\
Jumlah & 3 & 10 & 27 & 90 & 30 & 100 \\
\hline
\end{tabular}

Berdasarkan tabel 9 diketahui bahwa dari 30 responden terdapat 20 responden 
$(66,7 \%)$ yang melakukan teknik pelaksanaan IMD yang sesuai dan tidak mengalami perdarahan postpartum. Dan yang melakukan teknik pelaksanaan IMD yang sesuai tetapi tetap terjadi perdarahan postpartum yaitu sebanyak 1 responden (3,3\%). Dan yang melakukan teknik pelaksanaan IMD yang tidak sesuai tetapi tidak terjadi perdarahan sebanyak 7 responden (23,3\%). Hasil tabulasi silang antara teknik pelaksanaan IMD dengan kejadian perdarahan postpartum dihitung dengan menggunakan uji Chi Square. Namun, karena ada salah satu hasil perhitungan dari frekuensi harapan yang $<5$ yaitu 0,90 maka perhitungan dilakukan dengan menggunakan uji Fisher Exact dengan bantuan program pengolahan data dengan $\alpha=0,05$ dan diperoleh $\rho$ hitung $=0,207$ $>0,05$ maka H0 diterima artinya tidak ada hubungan antara teknik pelaksanaan IMD dengan kejadian perdarahan postpartum.

Berdasarkan hasil penelitian diketahui bahwa sebagian besar ibu bersalin di Wilayah Kerja Puskesmas Bungah Gresik melakukan teknik pelaksanaan IMD dengan benar dan terdapat $30 \%$ belum dilakukan dengan benar. Hal ini disebabkan ASI belum dapat keluar saat awal menyusui, ibu belum bisa bersikap dewasa seperti merasa geli jika bayi diletakkan diatas perut sehingga dalam melakukan asuhan IMD tenaga kesehatan (bidan) mengalami kesulitan. Alasan lain yang membuat ibu bersalin tidak melakukan teknik pelaksanaan IMD dengan benar adalah setelah melahirkan ibu merasa lelah, belum terlalu kuat untuk segera menyusui bayinya, kondisi anatomi organ menyusui yang tidak normal seperti puting susu datar atau tenggelam. Rendahnya pendidikan ibu tentang IMD dan anggapan bahwa susu formula memiliki kandungan gizi yang lengkap juga menjadi salah satu faktor penghambat dilakukannya teknik pelaksanaan IMD yang tidak sesuai (Musrifatul Uliyah, A. Aziz Alimul Hidayat, 2009).

Berdasarkan hasil penelitian diketahui bahwa sebagian besar yang melakukan teknik pelaksanaan IMD yang sesuai adalah ibu bersalin dengan usia 20-35 tahun, usia 20-35 tahun merupakan usia reproduktif dimana seorang wanita sudah mengetahui fungsi dari alat reproduksi yang dimilikinya, yakni rahim dan semua bagiannya, untuk tempat tumbuh kembang janin selama dalam kandungannya, dan payudara untuk dapat menyusui anak ketika anak sudah dilahirkan. Artinya semua wanita berpotensi untuk menyusui anaknya, sama dengan potensinya untuk mengandung dan melahirkan (Perinasia dalam Endah \& Masdinarsah, 2011).

Tidak semua wanita bisa memahami dan menghayati kodratnya. Hal ini disebabkan karena pengetahuan yang kurang memadai dan persepsi yang keliru tentang payudara dan menyusui, pemahaman yang kurang tentang peran dan fungsi ibu yang dapat dilihat dari usia ibu untuk menyusui, payudara tidak selalu dilihat sebagai perangkat untuk menyusui anaknya. Akibatnya ASI menjadi terbuang percuma. Ibu lebih suka menggunakan susu formula, padahal manfaat ASI sangat berguna untuk tumbuh kembang bayi.

Berdasarkan hasil penelitian diketahui bahwa $10 \%$ ibu primipara yang melakukan teknik pelaksanaan IMD yang salah. Hal ini bisa dipengaruhi oleh kurangnya rasa percaya diri ibu untuk menyusui bayinya. Ibu belum bisa beradaptasi dengan kondisi barunya setelah melahirkan. Kurangnya rasa percaya diri ibu mempengaruhi hipotalamus untuk memproduksi hormon prolaktin sehingga produksi ASI akan terhambat (Perinasia dalam Endah \& Masdinarsah, 2011).

Pada primipara asuhan terhadap teknik pelaksanaan IMD yang sesuai sering terhambat. Konseling saat ANC sangat dibutuhkan untuk meyakinkan ibu dan memberikan informasi dalam melakukan asuhan IMD setelah proses persalinan. Sehingga setelah proses persalinan asuhan terhadap teknik pelaksanaan IMD yang sesuai dapat terjadi.

Berdasarkan hasil penelitian diketahui ibu bersalin yang memiliki umur $<20$ tahun $(3,3 \%)$ mengalami perdarahan postpartum. Pada umur $<20$ tahun tergolong usia yang belum produktif. Resiko kehamilan lebih tinggi pada umur $<20$ tahun karena belum matangnya alat reproduksi untuk hamil sehingga dapat mengganggu kesehatan ibu maupun pertumbuhan dan perkembangan janin (Monita, 2016).

Ibu bersalin yang memiliki umur $>35$ tahun $(6,7 \%)$ yang mengalami perdarahan postpartum, pada umur $>35$ tahun tergolong kehamilan resiko tinggi. Menurut Nursalam dan Pariani (2001), ibu yang berumur $>35$ tahun 
lebih banyak dipengaruhi oleh proses penuaan. Pada proses penuaan akan terjadi perubahan metabolisme yaitu terjadi peningkatan jumlah lemak, penurunan penyerapan lemak, protein dan karbohidrat dan penurunan elastisitas otot. Penurunan regangan otot akan mempengaruhi kemampuan uterus untuk berkontraksi kembali ke bentuk semula setelah melahirkan sehingga membutuhkan waktu yang lama dibandingkan ibu yang masih dalam usia reproduktif. Kontraksi uterus terjadi karena zat protein dipecah, diserap dan dibuang bersama air kencing. Bila proses ini terganggu akibat proses penuaan maka akan menghambat kontraksi uterus. Kurun waktu reproduksi sehat adalah antara umur 20-35 tahun (Monita, 2016).

Kontraksi uterus juga dipengaruhi oleh paritas atau jumlah anak. Berdasarkan hasil penelitian diketahui terdapat $3.3 \%$ primipara $6.7 \%$ multipara yang mengalami perdarahan potpartum. Paritas mempengaruhi kontraksi uterus karena otot - otot uterus terlalu sering meregang sehingga elastisitas uterus juga berkurang. Dengan demikian untuk mengembalikan seperti keadaan semula setelah teregang memerlukan waktu yang lama.

Kontraksi uterus pada ibu bersalin berbeda-beda dan tergantung paritasnya. Semakin banyak jumlah anak maka semakin sering pula uterus mengalami peregangan. Selain peregangan uterus juga dipengaruhi oleh besar TFU yang terkadang karena bayi besar atau kehamilan oligohidramnion.

\section{Hubungan Teknik Pelaksanaan IMD dengan Kejadian Perdarahan Postpartum}

Hasil tabulasi silang antara teknik pelaksanaan IMD dengan kejadian perdarahan postpartum pada ibu bersalin bahwa presentase terbesar adalah ibu bersalin yang melakukan teknik pelaksanaan IMD dan tidak terjadi perdarahan postpartum mencapai $66,7 \%$. Berdasarkan uji Fisher Exact pada $\alpha=5 \%$ didapatkan nilai $\rho=0,207(\rho>0,05)$ maka H0 diterima artinya tidak ada hubungan antara teknik pelaksanaan IMD dengan kejadian perdarahan postpartum di Wilayah Kerja Puskesmas Bungah Gresik. Ada beberapa hal yang mendukung tidak adanya hubungan antara teknik pelaksanaan IMD dengan kejadian postpartum di Wilayah Kerja Puskesmas Bungah Gresik. Kepatuhan petugas kesehatan saat menolong persalinan (bidan) dalam hal penatalaksanaan MAK III, penanganan terhadap laserasi jalan lahir yang cepat dan tepat, dan juga penatalaksanaan menyusui dini yang optimal merupakan faktor - faktor yang mendukung terhadap penurunan kejadian perdarahan postpartum di Wilayah Kerja Puskesmas Bungah Gresik.

Berdasarkan hasil penelitian diketahui bahwa $23.3 \%$ ibu bersalin yang melakukan teknik pelaksanaan IMD salah tetapi tidak mengalami perdarahan postpartum. Hal ini diduga karena walaupun teknik pelaksanaan IMD tidak dilakukan dengan benar akan tetapi ketika menyusu dini kemampuan menghisap cukup kuat dan optimal sehingga reflek pengeluaran oksitosin dari kelenjar hipofise juga semakin lancar sehingga membantu mempercepat kontraksi uterus dan mempermudah pengeluaran plasenta. Sehingga tidak terjadi perdarahan postpartum.

Selain itu, pencegahan perdarahan postpartum juga didukung karena kepatuhan petugas kesehatan saat menolong persalinan (bidan) dalam melaksanakan Manajemen Aktif Kala II (MAK III). Karena dalam manajemen aktif kala tiga bertujuan untuk menghasilkan kontraksi uterus yang lebih efektif sehingga dapat mempersingkat waktu, mencegah perdarahan dan mengurangi kehilangan darah kala tiga persalinan jika dibandingkan dengan penatalaksanaan fisiologis. Sebagian besar kasus kesakitan dan dan kematian ibu di Indonesia disebabkan oleh perdarahan pascapersalinan dimana sebagian besar disebabkan oleh atonia uteri dan retensio plasenta yang sebenarnya dapat dicegah dengan melakukan manajemen aktif kala tiga.

Penanganan terhadap laserasi jalan lahir yang cepat dan tepat juga dapat mencegah terjadinya perdarahan postpartum. Adapun tujuan dari penjahitan laserasi adalah untuk menyatukan kembali jaringan pada tubuh (mendekatkan) dan mencegah kehilangan darah yang tidak perlu (memastikan hemostatis). Dan timbulnya infeksi postpartum dapat diminimalisir.

Teknik pelaksanaan IMD yang salah juga akan menyebabkan reflek hisap yang kurang maksimal pula sehingga pengeluaran oksitosin terhambat dan kontraksi uterus juga kurang maksimal. Hal ini membuktikan bahwa

Jurnal Kesehatan Vol. 6. No. 1. April 2018 | 11 
jika dengan melakukan teknik pelaksanaan IMD secara benar maka akan terjadi hisapan dimana hisapan bayi pada payudara ibu akan merangsang produksi oksitosin sehingga mempercepat kontraksi uterus dan mencegah terjadinya perdarahan postpartum. Selain itu juga, perlu diketahui bahwa hubungan teknik pelaksanaan IMD yang benar dan kejadian perdarahan postpartum juga dipengaruhi oleh faktor umur dan paritas.

\section{Simpulan dan Saran \\ 4.1 Simpulan}

Berdasarkan tujuan dan hasil yang dicapai dari proses penelitian, maka penulis dapat menyimpulkan sebagai berikut : Teknik Pelaksanaan IMD di Wilayah Kerja Puskesmas Bungah sebagian besar adalah tepat (sesuai), Kejadian Perdarahan Postpartum di Wilayah Kerja Puskesmas Bungah adalah rendah dan Tidak ada hubungan antara teknik pelaksanaan IMD dengan kejadian perdarahan postpartum di Wilayah Kerja Puskesmas Bungah Gresik.

\subsection{Saran}

Perlu dilakukan penelitian selanjutnya dengan melakukan penelitian pada faktor faktor lain yang dapat mempengaruhi terjadinya perdarahan postpartum. Dibutuhkan peningkatan komunikasi, pemberian informasi dan edukasi tentang pentingnya melakukan teknik pelaksanaan IMD yang sesuai sebagai pencegahan dan penanggulangan terjadinya perdarahan postpartum misalnya dengan cara menyebarkan leaflet, membentuk kelompok peminat KIA dan lain - lain.

\section{Daftar Pustaka}

Doenges, Marilynn. (2001). Rencana Perawatan Maternal. Jakarta : EGC.

Musrifatul Uliyah, A. Aziz Alimul Hidayat. (2009). Ketrampilan Dasar Praktek Klinik Untuk Kebidanan. Jakarta : Salemba Medika.

Saifuddin, Abdul Bari. (2002). Buku Acuan Nasional Pelayanan Kesehatan Maternal dan Neonatal. Jakarta: Yayasan Bina Pustaka Sarwono Prawirohardjo.
Palupi, D. D., \& Indawati, R. (2014). Faktor Risiko Kematian Ibu dengan Preeklampsia/Eklampsia dan Perdarahan di Provinsi Jawa Timur. Jurnal Biometrika dan Kependudukan. 3(2), 107-113.

Moedjiarto, S. (2011). Karakteristik Ibu Yang Berhubungan Dengan Perdarahan Post Partum Di RB Medika Utama Wonokupang Balongbendo Sidoarjo Tahun 2009. Jurnal Ilmiah Kesehatan Politeknik Kesehatan Majapahit Mojokerto 3(1).

Rusli, H. U. (2008). Inisiasi Menyusui Dini Plus ASI Eksklusif. Depok: Puspa Swara.

Awang, M. N. (2014). Pengetahuan dan Peran Suami sebagai Ayah tentang Inisiasi Menyusui Dini (IMD) dan Keberhasilan ASI Eksklusif pada Bayi 0-6 Bulan di Desa Raknamo Kecamatan Kabupaten Kupang Tahun 2011. Midwifery Medical Journal, 1(1), 63-70.

Endah, S. N., \& Masdinarsah, I. (2011). Pengaruh Pijat Oksitosin terhadap Pengeluaran Kolostrum pada Ibu Post Partum di Ruang Kebidanan Rumah Sakit Muhammadiyah Bandung tahun 2011. J. Kesehatan. Kartika, 1-9.

Monita, F. (2016). Hubungan usia, jarak kelahiran dan kadar hemoglobin ibu hamil dengan kejadian berat bayi lahir rendah di RSUD Arifin Achmad Provinsi Riau. Jurnal Online Mahasiswa Fakultas Kedokteran Universitas Riau, 2(2), 1-17. 